\title{
Forecasting the field performance of Austrian pine seedlings using morphological attributes
}

\author{
Vladan Ivetić( ${ }^{(1)}$, \\ Steven Grossnickle ${ }^{(2)}$, \\ Mirko Škorić ${ }^{(1)}$
}

\begin{abstract}
This study examined whether the morphological attributes of Austrian pine (Pinus nigra ssp. nigra var. nigra Arnold) seedlings measured in the nursery could be used to forecast subsequent field performance over an extended time frame. Seedlings from three seed sources were produced in two types of containers and in bareroot seedbeds. These seedlings were measured for an array of morphological attributes (height, HT; root collar diameter, RCD; shoot height/diameter ratio, HD; shoot and root dry weight, SDW and RDW, respectively; shoot:root ratio, S:R; number of the first order lateral roots, FOLR; and Dickson quality index, DQI) and then planted at two sample plots with different soil depth. Seedling attributes were tested against field survival and growth in the first three years and growth in the twelfth year for their ability to forecast field performance. Correlations between morphological attributes and field performance were stronger for the plot with shallower soil, having potentially drier conditions. HT, HD, and S:R were the best attributes for forecasting seedling survival. HD was the most reliable attribute to forecast growth during the first three years after planting, defining the largest proportion of variation for growth $\left(r^{2}=0.36\right.$ to 0.86$)$. Morphological attributes were better able to forecast field performance in the first three years at the shallow soil site, with FOLR the best single morphological variable. HT, DIA, and RDW were the best attributes to forecast growth during the first three years after planting on both sites. Morphological attributes were not able to forecast growth 12 years after planting.
\end{abstract}

Keywords: Seedling Quality, Seedling Performance, Reforestation, Pinus nigra considered. First, the choice of planting material should be based on operational seedling standards. Second, seedling quality attributes should be selected based on their use within reforestation programs. Third, confirmation of these standards in the field should be related to the typical reforestation site environment. There is no single and universal test of seedling quality. Separate testing standards need to be developed for seedlings produced from various combinations of species, seed lots, and nursery culture (Grossnickle \& Folk 1993). Stock types should be tested in field trials for a number of years to ensure a representative assessment of field performance (Pinto et al. 2011a). Between lifting and planting, seedlings are potentially ex-
(1) University of Belgrade, Faculty of Forestry, Kneza Viseslava 1, 11030 Belgrade (Serbia); (2) NurseryToForest Solutions, 1325 Readings Drive, Sidney V8L 5K7, British Columbia (Canada)

@ Ivetić Vladan (vladan.ivetic@sfb.bg.ac.rs)

Received: May 29, 2015 - Accepted: Jun 20, 2016

Citation: Ivetić V, Grossnickle S, Škorić M (2016). Forecasting the field performance of Austrian pine seedlings using morphological attributes. iForest 10: 99-107. - doi: 10.3832/ifor1722-009 [online 2016-10-13]

Communicated by: Mike Perks posed to numerous stresses (McKay 1997, Grossnickle \& South 2014). Moreover, environmental conditions differ between sites and even between single planting spots (Grossnickle 2000). This can result in a misleading perspective about the value of seedling quality assessment and should be considered during the selection of plant attributes for use in operational reforestation programs.

Seedling morphology remains the basis for stock type characterization (Thompson 1985, Ivetić \& Devetaković 2016), and morphological parameters are the most widely used attributes measured in seedling quality assessment (Thompson 1985, Mexal \& Landis 1990). The use of morphological attributes to forecast post-planting survival and growth varies. Savings from quality testing for seedling survival are substantial, but gains from growth are more tenuous (Dunsworth 1997). In a number of trials, the initial seedling morphological attributes were able to forecast growth (e.g., Ward et al. 2000, Rose \& Ketchum 2003) over a longer time frame than survival (Pinto et al. 2011b). Many studies showed a relationship between the initial morphological attributes and post-planting success (Mexal \& Landis 1990, South et al. 2005, Mexal et al. 2009, Oliet et al. 2009, Grossby species, especially under dry conditions nickle 2012), but specific attributes varied 


\section{(Tsakaldimi et al. 2012).}

Austrian pine (Pinus nigra Arnold) is one of the most economically important native conifers in southern Europe and one of the most widely planted species in Serbian afforestation programs, with 106,389 ha of plantations established between 1961 and 2007 (Ranković 2009), and planting of this species continues to increase (Ivetić \& Vilotić 2014). Average survival of Austrian pine seedlings is only $71 \%$, and it strongly depends on stock type (Ivetić 2015). This low field survival level likely indicates the need for quality attributes that can be used to grade Austrian pine seedlings, thereby improving their field performance. Accordingly, the objective of this study was twofold. First, define a set of morphological attributes that can be used to forecast field performance for a broad range of Austrian pine stock types. Second, determine whether morphological attributes that forecast short-term field performance have the potential to forecast longer-term field performance of Austrian pine.

\section{Material and methods}

\section{Seedling production}

Two-year old Austrian pine (Pinus nigra ssp. nigra var. nigra Arnold) seedlings were produced in the nursery of Education and Research Base Goč - Faculty of Forestry, University of Belgrade (850 m a.s.l.). Three seed sources and three stock types were used in the trial. The three seed sources came from the following locations: source \#1: latitude $43^{\circ} 33^{\prime} 06^{\prime \prime} \mathrm{N}$, longitude $20^{\circ} 40^{\prime}$ $54^{\prime \prime} \mathrm{E}$, elevation $780 \mathrm{~m}$ a.s.l.; source \#2: $43^{\circ}$ $26^{\prime} 58^{\prime \prime} \mathrm{N}, 20^{\circ} 31^{\prime} 51^{\prime \prime} \mathrm{E}, 930 \mathrm{~m}$ a.s.l.; source \#3, 43 $51^{\prime} 14^{\prime \prime} \mathrm{N}, 19^{\circ} 33^{\prime} 43^{\prime \prime}, 1100 \mathrm{~m}$ a.s.l. Two container stock types and one bareroot stock type were produced for this trial. Gocko containers of plastic film (Ivetić \& Škorić 2013) had tray dimensions of $30 \mathrm{~cm}$ long (L) $\times 15 \mathrm{~cm}$ wide $(\mathrm{W})$, with 18 square cross section bottomless cells, dimensions of $5 \mathrm{~cm} \mathrm{~L} \times 5 \mathrm{~cm} \mathrm{~W} \times 15 \mathrm{~cm}$ high $(\mathrm{H})$ and a cell volume of $375 \mathrm{~cm}^{3}$, with growing density of 400 seedlings per $\mathrm{m}^{2}$. Plantagrah II containers had tray dimensions of $32 \mathrm{~cm} \mathrm{~L}$ $\times 21.5 \mathrm{~cm} \mathrm{~W}$, with 33 hexagon cross section at top and circular at bottom cells with vertical ribs on the inner side walls, dimensions of $5 \mathrm{~cm}$ diameter $\times 18 \mathrm{~cm} \mathrm{H}$, with drainage hole at the bottom of $1.5 \mathrm{~cm}$, three side holes, a cell volume of $270 \mathrm{~cm}^{3}$, and growing density of 480 seedlings per $\mathrm{m}^{2}$. A substrate of $50 \%$ peat plus $50 \%$ humified bark and sawdust of beech and fir was used for growing all container types. For bareroot seedlings, the top $15 \mathrm{~cm}$ of existing seedbeds was replaced with the same substrate. This medium has been used as a replacement for seasonal fertilization within operational forest nursery programs in Serbia. Seed was sown in both container types and in bareroot seedbeds in mid-May 1997. Two seeds per cell were sown in containers and $30 \mathrm{~g}$ of seed per $\mathrm{m}^{2}$ broadcast in seedbeds. In cases where two germi- nants emerged in the same container cell, the less developed germinant was removed. The bareroot seedbeds were thinned to a density of 500 seedlings per $\mathrm{m}^{2}$.

Standard nursery cultural practices for Austrian pine seedlings (Stilinović 1987) were used to grow all three stocktypes. Germinants were treated with $2 \%$ Benomile fungicide (Benfungin WP ${ }^{\circledast}$, Galenika Fitofarmacija, Serbia) to prevent damping-off in the first three weeks after emergence. All stock types were shaded with plastic nets (60\% shade) until mid-August, from 11:0016:00 daily. Stock types were irrigated with above-ground fixed sprinklers every second night with $1.5 \mathrm{~L}$ per $\mathrm{m}^{2}$, if $<4 \mathrm{~mm}$ of precipitation had not been recorded in the previous two days. Manual weeding was performed as needed. In the second nursery growing season, only irrigation and weeding were performed. Toward the end of both nursery growing seasons, irrigation was ended in mid-August, in order to induce water stress and to promote hardening. There was no root culturing (e.g., undercutting and/or wrenching) for bareroot seedlings. Seedlings were covered by snow during winter and there was no danger of frost damage. After the second year, dormant seedlings (i.e., no bud break due to the nursery's high elevation) were lifted in early April.

Seedlings were lifted at the nursery and transported to the planting site one hour prior to planting, in order to minimize detrimental changes in physiological status between lifting and planting. Bareroot seedlings were manually lifted from seedbeds, covered with wet sheets, and transported to the planting site in tractor-trailers. Container seedlings were transported to the planting site in trays and lifted from cells immediately before planting.

\section{Stock quality assessment}

A random sample of 378 seedlings (42 seedlings $\times 3$ seed sources $\times 3$ stock types $15 \%$ of total number of seedling produced for this trial) were measured for shoot height (HT), root collar diameter (DIA), shoot height/diameter ratio (HD), shoot and root dry weight (SDW and RDW, respectively), shoot:root ratio (S:R), number of the first order lateral roots (FOLR), and Dickson quality index (DQI). At this point in the study, the seed sources were considered as treatment and their effect on seedling development was tested. Following the previously published results (Ivetić \& Škorić 2013), seed sources were no longer considered as treatments in the field assessment, but used as replications. Seedlings were sampled at lifting and sent to the laboratory for morphological assessment at the Faculty of Forestry, University of Belgrade.

The HT was measured as the distance between the root collar and base of terminal bud of dormant seedlings, with an accuracy of $0.1 \mathrm{~cm}$. The DIA was measured at or near the root collar with an accuracy of $0.1 \mathrm{~mm}$. Shoots were separated from roots at the root collar and oven dried in open paper bags for 48 hours at $80{ }^{\circ} \mathrm{C}$. Shoot and root dry weights were measured on an electronic scale (accuracy +/$0.001 \mathrm{~g})$. The HD was calculated as the ratio between height $(\mathrm{cm})$ and diameter $(\mathrm{mm})$. The S:R ratio was calculated as the ratio between shoot and root dry weights $\left(\mathrm{g} \mathrm{g}^{-1}\right)$. Number of first order lateral roots was established as the number of roots with diameter $>1 \mathrm{~mm}$ at proximal end. The Dickson quality index was calculated using eqn. $1:$

$$
D Q I=\frac{S D W+R D W}{H D+S: R}
$$

\section{Field site}

Seedlings were planted in early April 1999 on a field site of the Faculty of Forestry, University of Belgrade, at mountain Goč in Central Serbia (latitude $43^{\circ} 34^{\prime} 26^{\prime \prime} \mathrm{N}$, longitude $20^{\circ} 40^{\prime} 52^{\prime \prime} \mathrm{E}$ and elevation $730-790 \mathrm{~m}$ a.s.l.). At the field site, two sample plots (SP) were established, both on the same slope of $27^{\circ}$, bordering each other: one with deeper (SP1 - humus layer A of $30 \mathrm{~cm}$ with profile $A-A C-R$, at lower part of the slope) and one with shallow ( $\mathrm{SP}_{2}$ - humus layer A of $15 \mathrm{~cm}$ with same profile, at higher part of the slope) soil (same soil type - humus silicate eutric soil on serpentinite - Škorić et al. 1985). A total of 891 planting holes per SP, with diameter of 25 $\mathrm{cm}$ at both SP and depth of $40 \mathrm{~cm}$ at SP1 and $25 \mathrm{~cm}$ at SP2, were prepared with a mechanical auger one day prior to planting. On spots where the drill was not able to penetrate into the soil, holes were prepared manually to desired dimensions. Seedlings were planted in one day per SP, in square, multiple-tree plots (South \& Foster 1993).

\section{Field assessment}

The randomized complete block design used in the nursery phase of the study was repeated in the field with three stock types and three replications (nine experimental units), meaning that seedlings from one nursery block were kept together and planted in the same field block. The outer three rows of seedlings from each plot were treated as buffer rows and excluded from the study. Each sample plot consisted of 33 rows with 27 planting spots in each row (total of 891 planting spots), with dimensions of $41.25 \times 33.75 \mathrm{~m}$. Spacing between rows and seedlings within the row was $1.25 \mathrm{~m}$ at time of planting. After each of the first three growing seasons, a total of 378 seedlings (189 seedlings at each SP) were removed (21 from each experimental unit), resulting in space between rows of $2.5 \mathrm{~m}$ after the third growing season, with final density of 1,600 seedlings per hectare. During the initial three growing seasons, weeds were mechanically or manually removed as re- 
Tab. 1 - Mean values of Austrian pine seedlings morphological attributes height (HT), diameter (DIA), height to diameter (HD), shoot dry weight (SDW), root dry weight (RDW), shoot to root dry weight (S:R), number of first order lateral roots (FOLR) and Dickson Quality Index (DQI) at time of lifting from the nursery (standard deviation in parenthesis). All mean values were statistically different $(p=0.0000)$. Mean values in the same row followed with different letter were significantly different. ( $\neq)$ : As defined by Serbian standard for coniferous seedlings quality SRPS D.Z2.111 (i.e., official document by Institute for Standardization of Serbia).

\begin{tabular}{|c|c|c|c|c|c|c|}
\hline \multirow{2}{*}{$\begin{array}{l}\text { Morphological } \\
\text { attribute }\end{array}$} & \multirow{2}{*}{ Gocko } & \multirow{2}{*}{ Plantagrah II } & \multirow{2}{*}{ Bareroot } & \multirow{2}{*}{ Min-Max } & \multicolumn{2}{|c|}{ Minimum for ${ }^{(\ddagger)}$} \\
\hline & & & & & $1^{\text {st }}$ class & $2^{\text {nd }}$ class \\
\hline HT (cm) & $9.40 \pm 1.65^{a}$ & $9.44 \pm 1.59^{a}$ & $11.16 \pm 1.33^{b}$ & $8.29-11.64$ & 12 & 8 \\
\hline DIA (mm) & $4.04 \pm 0.76^{b}$ & $3.34 \pm 0.47^{a}$ & $3.19 \pm 0.52^{a}$ & $2.86-4.40$ & 3 & 2 \\
\hline $\mathrm{HD}$ & $2.37 \pm 0.45^{\mathrm{a}}$ & $2.85 \pm 0.49^{b}$ & $3.55 \pm 0.51^{c}$ & $2.08-4.01$ & - & - \\
\hline SDW (g) & $2.20 \pm 0.88^{b}$ & $1.48 \pm 0.48^{a}$ & $1.72 \pm 0.50^{a}$ & $1.33-2.78$ & - & - \\
\hline RDW (g) & $1.03 \pm 0.46^{c}$ & $0.70 \pm 0.21^{b}$ & $0.54 \pm 0.18^{a}$ & $0.22-2.57$ & - & - \\
\hline$S: R$ & $2.22 \pm 0.47^{\mathrm{a}}$ & $2.17 \pm 0.50^{a}$ & $3.29 \pm 0.73^{b}$ & $1.26-6.17$ & - & - \\
\hline FOLR & $10.19 \pm 1.96^{c}$ & $8.19 \pm 1.53^{b}$ & $6.78 \pm 1.90^{a}$ & $3.00-15.00$ & - & - \\
\hline DQI & $0.73 \pm 0.36^{c}$ & $0.44 \pm 0.15^{b}$ & $0.34 \pm 0.12^{a}$ & 0.14-1.95 & - & - \\
\hline
\end{tabular}

quired. After three growing seasons, no further vegetation management control was performed.

After each of the first three growing seasons, a total of 378 seedlings were sampled (21 seedlings $\times 3$ stocktypes $\times 3$ repetitions $\times 2$ SP), and the same morphological attributes measured at planting were re-measured. Total height and diameter were measured the twelfth year after planting for all remaining plants. Diameter was measured in year 12 at both $1.3 \mathrm{~m}(\mathrm{DBH})$ and at $10 \mathrm{~cm}$ (D12), because some plants did not reach over $1.3 \mathrm{~m}$ height.

In the first and third year after planting, temperatures were the same as and precipitation was above regional averages. The second year after planting was hot and dry, with temperatures above (i.e., 139\%) and precipitation slightly lower than regional averages, resulting in a site water deficit during this growing season (see Supplementary Material).

\section{Statistical analysis}

From each stock type in the nursery, a sample of 126 seedlings (126 seedlings $\times 3$ stocktypes $=378$ ) was measured at lifting and one-way ANOVA was used to test differences between mean values of attributes. Mean values were separated using Tukey's HSD test, with a significance level of $p<0.05$. The stock type data were combined due to previously established absence of significant differences between correlation coefficients from three stock types. Pooling of stock type data was also done to meet the study objective to define a set of morphological attributes that could be used to forecast field performance across a broad range of stock types and site conditions.

At each SP, a total of 27 subsamples consisting of seven seedlings from the same experimental units (i.e., 7 seedlings $\times 27$ subsamples $=189$ ) were measured, and mean values of these subsamples (ecological correlation) were used for calculation of two-tailed Pearson correlation coefficients $(R)$ between initial values and values measured after each growing season. A simple linear regression analysis using the least squares method was performed to calculate regression lines for model $y=a+$ $b x$, in order to establish the simple forecasting model for Austrian pine. Linear regression analysis determined the value of using initial seedling quality attributes in forecasting growth performance after planting only in cases where correlation coefficients were $>0.50$. Coefficient of determination $\left(r^{2}\right)$ was then calculated on these relationships with a correlation coefficient $>0.50$ to examine the proportion of the variance shared by both variables.

\section{Results}

At lifting, Austrian pine seedlings from three stock types met all current acceptable standards for a plantable seedling for Serbian reforestation programs (Tab. 1). Bareroot seedlings showed the largest $\mathrm{HT}$, but smallest DIA, resulting in the largest HD. They also had the smallest RDW, re- sulting in the largest S:R. Bareroot seedlings also had the lowest FOLR and DQI. Seedlings produced in Gocko containers had the largest values for morphological attributes DIA, SDW, RDW, FOLR, and DQI, and the smallest value for HT and HD. The Plantagrah II stock type had morphological features that were, for the most part, intermediate between the other two stock types.

The sample plot characteristics (SP) significantly influenced survival and growth of Austrian pine seedlings. Seedling survival was much lower at the site with shallower soil ( $\left.\mathrm{SP}_{2}\right)$, with the greatest mortality observed in bareroot seedlings (Tab. 2). Seedling growth was much greater at SP1. Differences in growth between $\mathrm{SP}_{1}$ and $\mathrm{SP} 2$ increased with time (Fig. 1). At year 12, plants at SP2 were approximately one-half the size of plants at SP1. The largest seed-

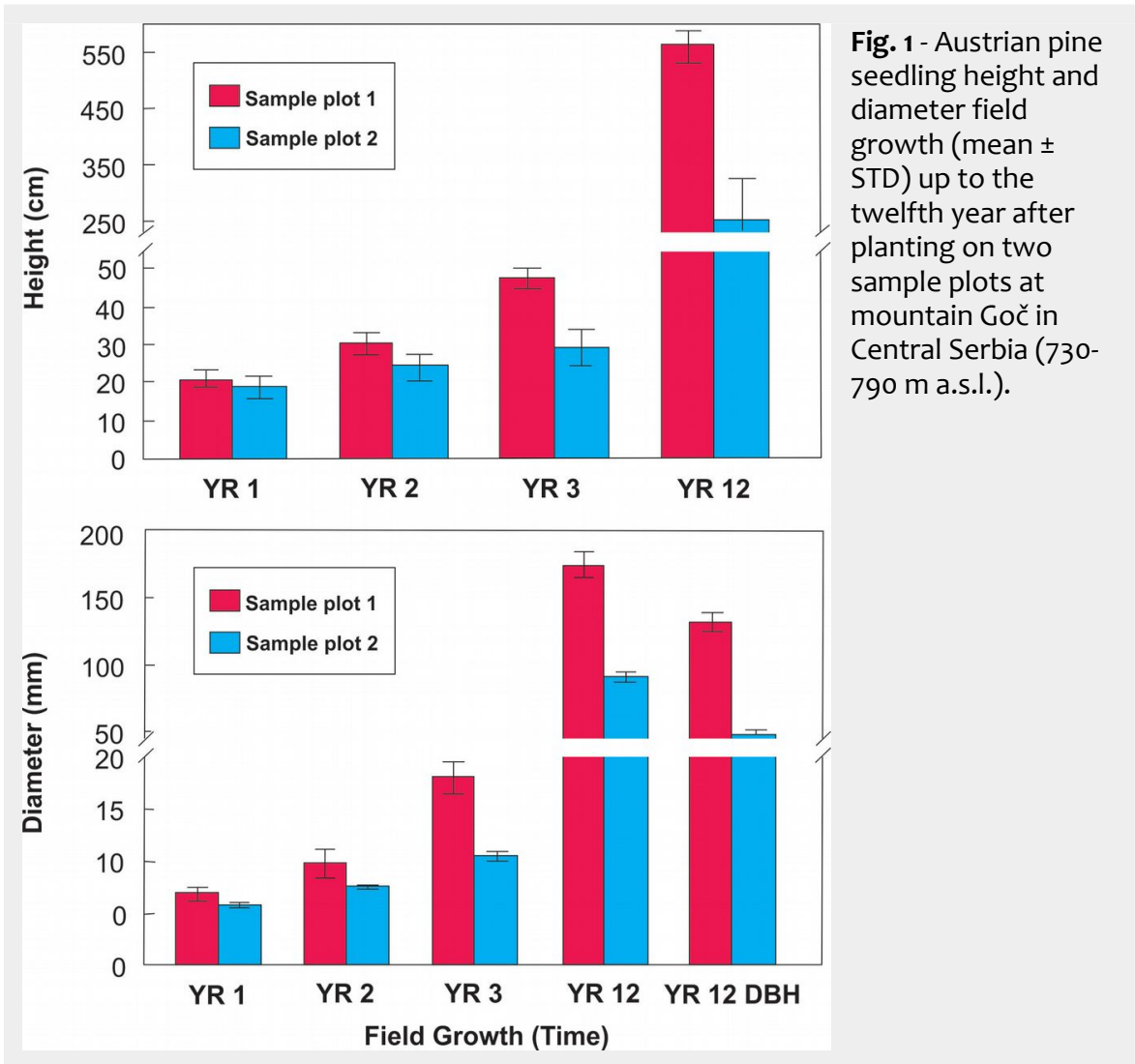


Tab. 2 - Survival (\%) of Austrian pine seedlings for various stock types in first three years after planting on two sample plots at the field site.

\begin{tabular}{lcccccc}
\hline \multirow{2}{*}{$\begin{array}{l}\text { Stock } \\
\text { type }\end{array}$} & \multicolumn{2}{l}{ Sample plot $\mathbf{1}$} & \multicolumn{4}{c}{ Sample plot $\mathbf{2}$} \\
\cline { 2 - 7 } & $\mathbf{1}^{\text {st }}$ year & $\mathbf{2}^{\text {nd }}$ year & $\mathbf{3}^{\text {rd }}$ year & $\mathbf{1}^{\text {st }}$ year & $\mathbf{2}^{\text {nd }}$ year & $\mathbf{3}^{\text {rd }}$ year \\
\hline Gocko & 98.8 & 98.4 & 98.4 & 98.5 & 95.1 & 94.7 \\
Plantagrah II & 99.2 & 98.4 & 98.4 & 98.8 & 91.4 & 90.5 \\
Bareroot & 97.9 & 95.9 & 95.9 & 87.3 & 71.2 & 68.7 \\
Average & 98.6 & 97.6 & 97.6 & 94.9 & 85.9 & 84.6 \\
\hline
\end{tabular}
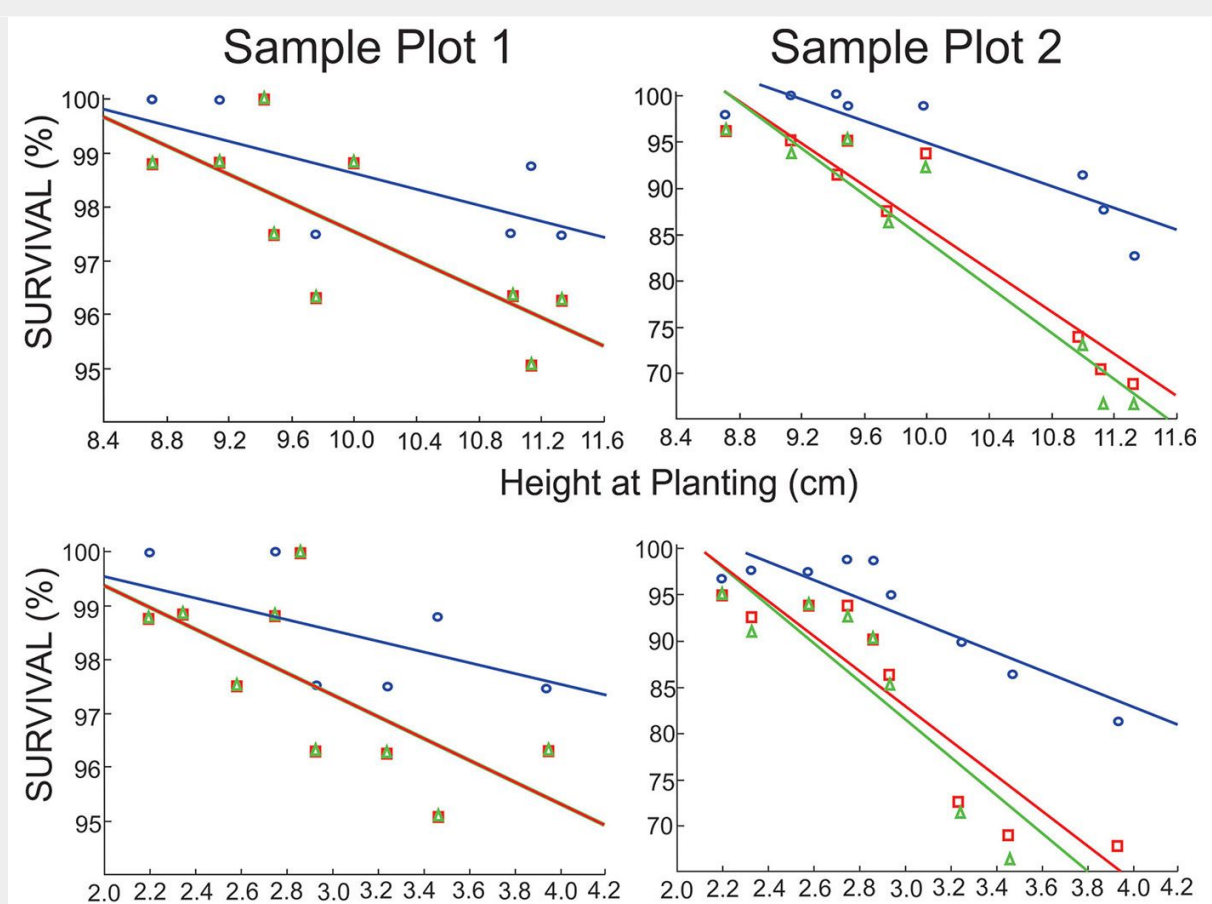

Shoot Height/Diameter Ratio
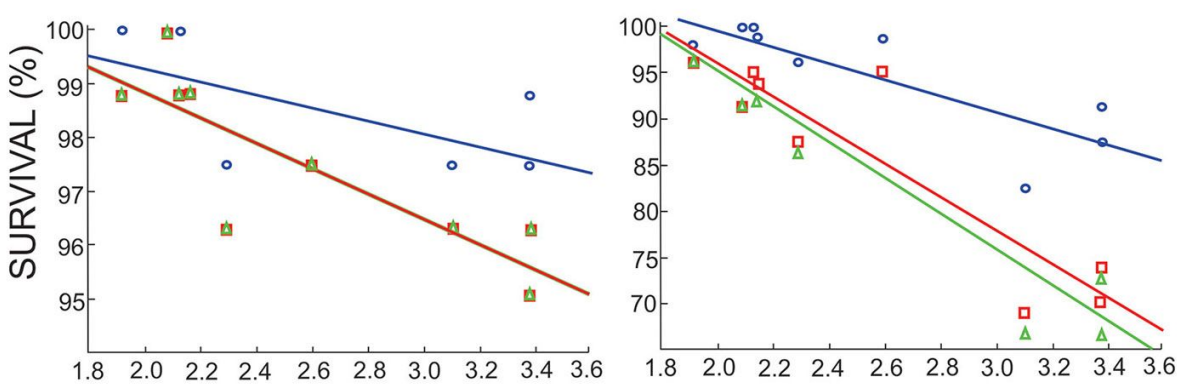

Shoot:Root Ratio lings at $\mathrm{SP} 2$ were smaller than the smallest seedlings at SP1.

Initial seedling $H T, H D$, and $S: R$ ratios were negatively related to survival during years one to three in the field (Fig. 2, Tab. 3). These negative correlations with survival were much stronger at the drier site having a shallower soil profile (SP2). Initial seedling DIA was positively related to survival only in the second year after planting
Fig. 2 - The relationship of initial height, shoot height to diameter ratio, and shoot to root dry weight ratio of Austrian pine seedlings measured just prior to planting to survival after one, two, and three years of field growth at both sample plots. Coefficient of correlations for initial morphological attributes and field survival after planting are given in Tab. 3. Note: Coefficient of correlations at sample plot 1 are equal for years 2 and 3 .

\section{$\backslash$ Year $1 \backslash$ Year $2 \backslash$ Year 3}

Tab. 3 - Pearson's coefficients of correlation between values of initial morphological attributes height (HT), diameter (DIA), height to diameter (HD), shoot dry weight (SDW), root dry weight (RDW), shoot to root dry weight (S:R), number of first order lateral roots (FOLR) and Dickson Quality Index (DQI) of Austrian pine seedlings measured at lift and survival in first three years after plant ing on two sample plots at the field site $(N=9) .(* *): p<0.01 ;(*): p<0.05$.

\begin{tabular}{lcccccc}
\hline $\begin{array}{l}\text { Morphological } \\
\text { Attribute }\end{array}$ & \multicolumn{2}{l}{ Sample plot $\mathbf{1}$} & \multicolumn{3}{c}{ Sample plot 2 } \\
\cline { 2 - 7 } & $\mathbf{1}^{\text {st }}$ year & $\mathbf{2}^{\text {nd }}$ year & $\mathbf{3}^{\text {rd }}$ year & $\mathbf{1}^{\text {st }}$ year & $\mathbf{2}^{\text {nd }}$ year & $\mathbf{3}^{\text {rd }}$ year \\
\hline HT & -0.61 & $-0.77^{*}$ & $-0.77^{*}$ & $-0.89^{* *}$ & $-0.95^{* *}$ & $-0.95^{* *}$ \\
DIA & 0.27 & 0.49 & 0.49 & 0.62 & $0.67^{*}$ & 0.66 \\
HD & -0.48 & $-0.69^{*}$ & $-0.69^{*}$ & $-0.89^{* *}$ & $-0.92^{* *}$ & $-0.92^{* *}$ \\
SDW & -0.08 & 0.09 & 0.09 & 0.21 & 0.27 & 0.26 \\
RDW & 0.37 & 0.58 & 0.58 & 0.61 & $0.72^{*}$ & $0.71^{*}$ \\
S:R & -0.61 & $-0.84^{* *}$ & $-0.84^{* *}$ & $-0.82^{* *}$ & $-0.91^{* *}$ & $-0.91^{* *}$ \\
FOLR & 0.10 & 0.57 & 0.57 & $0.68^{*}$ & $0.78^{*}$ & $0.78^{*}$ \\
DQI & 0.36 & 0.56 & 0.56 & 0.60 & $0.71^{*}$ & $0.70^{*}$ \\
\hline
\end{tabular}


Tab. 4 - Pearson coefficients of correlations between values of initial morphological attributes height (HT), diameter (DIA), height to diameter (HD), shoot dry weight (SDW), root dry weight (RDW), shoot to root dry weight (S:R), number of first order lateral roots (FOLR) and Dickson Quality Index (DQI) of Austrian pine seedlings measured at lift with HT and DIA after one, two, three and 12 years after planting on two sample plots at the field site $(N=27) .(* *): p<0.01 ;(*): p<0.05$

\begin{tabular}{|c|c|c|c|c|c|c|c|c|c|c|}
\hline Sample Plot & $\begin{array}{l}\text { Morphological } \\
\text { Attribute }\end{array}$ & HT1 & HT2 & НT3 & HT12 & DIA1 & DIA2 & DIA3 & DBH & D12 \\
\hline \multirow{8}{*}{$\begin{array}{l}\text { SP1 (absolute } \\
\text { values) }\end{array}$} & $\mathrm{HT}$ & $-0.68^{* *}$ & $-0.56^{* *}$ & $-0.63^{* *}$ & 0.17 & $-0.76^{* *}$ & $-0.73^{* *}$ & $-0.81^{* *}$ & -0.10 & 0.13 \\
\hline & DIA & $0.45^{*}$ & $0.74^{* *}$ & $0.42^{*}$ & 0.26 & $0.72^{* *}$ & $0.81^{* *}$ & $0.74^{* *}$ & $0.53^{* *}$ & 0.23 \\
\hline & $\mathrm{HD}$ & $-0.67^{* *}$ & $-0.75^{* *}$ & $-0.60^{* *}$ & -0.09 & $-0.87^{* *}$ & $-0.88^{* *}$ & $-0.89^{* *}$ & -0.35 & -0.05 \\
\hline & SDW & 0.08 & $0.50^{* *}$ & 0.09 & 0.35 & $0.44^{*}$ & $0.53^{* *}$ & 0.37 & $0.55^{* *}$ & 0.35 \\
\hline & RDW & $0.48^{*}$ & $0.74^{* *}$ & $0.46^{*}$ & 0.30 & $0.77^{* *}$ & $0.84^{* *}$ & $0.81^{* *}$ & $0.63^{* *}$ & 0.28 \\
\hline & $S: R$ & $-0.68^{*}$ & $-0.59^{*}$ & $-0.62^{*}$ & -0.11 & $-0.76^{*}$ & $-0.76^{*}$ & $-0.89^{*}$ & -0.35 & -0.06 \\
\hline & FOLR & $0.40^{*}$ & $0.66^{* *}$ & $0.39^{*}$ & 0.29 & $0.62^{* *}$ & $0.80^{* *}$ & $0.75^{\text {** }}$ & $0.50^{* *}$ & 0.33 \\
\hline & DQI & $0.48^{*}$ & $0.75^{*}$ & $0.46^{*}$ & 0.25 & $0.78^{* *}$ & $0.86^{* *}$ & $0.80^{* *}$ & $0.60^{* *}$ & 0.26 \\
\hline \multirow{8}{*}{$\begin{array}{l}\text { SP2 (absolute } \\
\text { values) }\end{array}$} & $\mathrm{HT}$ & $-0.69^{* *}$ & $-0.57^{* *}$ & $-0.40^{*}$ & -0.06 & $-0.71^{\text {** }}$ & $-0.81^{* *}$ & $-0.51^{* *}$ & -0.05 & -0.07 \\
\hline & DIA & $0.60^{\text {** }}$ & $0.68^{* *}$ & $0.77^{\text {** }}$ & 0.07 & $0.84^{* *}$ & $0.77^{* *}$ & $0.89^{* *}$ & 0.11 & 0.08 \\
\hline & $\mathrm{HD}$ & $-0.76^{* *}$ & $-0.75^{* *}$ & $-0.69^{* *}$ & -0.06 & $-0.92^{* *}$ & $-0.93^{* *}$ & $-0.80^{* *}$ & -0.08 & -0.06 \\
\hline & SDW & 0.20 & 0.31 & $0.59^{* *}$ & 0.10 & $0.50^{* *}$ & $0.39^{*}$ & $0.72^{* *}$ & 0.17 & 0.11 \\
\hline & RDW & $0.58^{* *}$ & $0.58^{* *}$ & $0.69^{* *}$ & 0.15 & $0.78^{* *}$ & $0.77^{* *}$ & $0.84^{* *}$ & 0.23 & 0.18 \\
\hline & $S: R$ & $-0.76^{* *}$ & $-0.62^{* *}$ & $-0.50^{* *}$ & -0.14 & $-0.73^{* *}$ & $-0.83^{* *}$ & $-0.55^{* *}$ & -0.17 & -0.14 \\
\hline & FOLR & $0.62^{* *}$ & $0.77^{* *}$ & $0.81^{* *}$ & 0.27 & $0.79^{* *}$ & $0.81^{* *}$ & $0.89^{* *}$ & 0.28 & 0.25 \\
\hline & $\mathrm{DQI}$ & $0.57^{* *}$ & $0.59^{* *}$ & $0.70^{* *}$ & 0.13 & $0.79^{* *}$ & $0.77^{* *}$ & $0.86^{* *}$ & 0.20 & 0.15 \\
\hline
\end{tabular}

Tab. 5 - Linear regressions and coefficients of determination $\left(r^{2}\right)$ of morphological attributes height (HT), diameter (DIA), height to diameter (HD), shoot dry weight (SDW), root dry weight (RDW), shoot to root dry weight (S:R), number of first order lateral roots (FOLR) and Dickson Quality Index (DQI)at time of lifting from the nursery and height and diameter growth after one, two, three and 12 years of field growth of Austrian pine seedlings after planting on two sample plots at the field site. Linear regression was calculated only where correlation coefficients were $>0.50$.

\begin{tabular}{|c|c|c|c|c|}
\hline \multirow{2}{*}{$\begin{array}{l}\text { Morphological } \\
\text { Attribute }\end{array}$} & \multicolumn{2}{|l|}{ Sample Plot 1} & \multicolumn{2}{|l|}{ Sample Plot 2} \\
\hline & Regression Equation & $r^{2}$ & Regression Equation & $r^{2}$ \\
\hline \multirow{5}{*}{ HT } & $\mathrm{HT} 1=37.1506-1.5977 \mathrm{HT}$ & 0.46 & $\mathrm{HT} 1=40.0955-2.1185 \mathrm{HT}$ & 0.48 \\
\hline & $\mathrm{HT} 2=47.4734-1.7311 \mathrm{HT}$ & 0.31 & $\mathrm{HT} 2=42.2593-1.7976 \mathrm{HT}$ & 0.32 \\
\hline & $\mathrm{DIA} 1=12.4528-0.5614 \mathrm{HT}$ & 0.58 & $\mathrm{DIA} 2=18.0044-1.0572 \mathrm{HT}$ & 0.66 \\
\hline & DIA2 $=20.3079-1.0602 \mathrm{HT}$ & 0.53 & $\mathrm{DIA} 3=21.5505-1.1135 \mathrm{HT}$ & 0.26 \\
\hline & DIA3 $=30.8686-1.2837 \mathrm{HT}$ & 0.66 & - & - \\
\hline \multirow[t]{5}{*}{ DIA } & $\mathrm{HT} 2=11.1181+5.3968 \mathrm{DIA}$ & 0.55 & $\mathrm{HT} 1=3.7259+4.3023 \mathrm{DIA}$ & 0.36 \\
\hline & DIA2 $=-0.0304+2.7589$ DIA & 0.66 & HT3 $=-1.8785+8.8318$ DIA & 0.59 \\
\hline & DIA3 $=8.3267+2.7499 \mathrm{DIA}$ & 0.55 & DIA1 $=-0.3675+1.7213$ DIA & 0.70 \\
\hline & $\mathrm{DBH}=9.9848+0.9073 \mathrm{DIA}$ & 0.28 & $\mathrm{DIA} 2=-0.8791+2.3549 \mathrm{DIA}$ & 0.59 \\
\hline & - & - & DIA3 $=-5.7685+4.5864$ DIA & 0.79 \\
\hline \multirow[t]{5}{*}{ HD } & $\mathrm{HT} 1=29.5589-2.8686 \mathrm{HD}$ & 0.45 & $\mathrm{HT} 1=31.3456-4.2539 \mathrm{HD}$ & 0.58 \\
\hline & $\mathrm{HT} 2=42.4658-4.2083 \mathrm{HD}$ & 0.56 & $\mathrm{HT2}=36.7962-4.2801 \mathrm{HD}$ & 0.56 \\
\hline & $\mathrm{HT} 3=56.5776-3.1645 \mathrm{HD}$ & 0.36 & $\mathrm{HT} 3=47.284-6.1559 \mathrm{HD}$ & 0.48 \\
\hline & $\mathrm{DIA} 1=10.2632-1.1713 \mathrm{HD}$ & 0.76 & DIA1 $=9.9748-1.4599 \mathrm{HD}$ & 0.85 \\
\hline & $\mathrm{DIA} 2=16.4968-2.3229 \mathrm{HD}$ & 0.77 & $\mathrm{DIA} 2=13.8846-2.2073 \mathrm{HD}$ & 0.86 \\
\hline \multirow[t]{2}{*}{ SDW } & DIA2 $=6.1368+1.9785$ SDW & 0.28 & HT3 $=15.9293+7.4069$ SDW & 0.35 \\
\hline & $\mathrm{DBH}=11.3098+1.0407 \mathrm{SDW}$ & 0.30 & $\mathrm{DIA} 3=3.0469+4.0863 \mathrm{SDW}$ & 0.52 \\
\hline \multirow[t]{6}{*}{ RDW } & $\mathrm{HT} 2=23.1813+9.2206 \mathrm{RDW}$ & 0.55 & $\mathrm{HT} 1=13.4967+7.1472 \mathrm{RDW}$ & 0.33 \\
\hline & $\mathrm{DIA} 1=5.0949+2.3031 \mathrm{RDW}$ & 0.59 & $\mathrm{HT} 2=18.7717+7.2781 \mathrm{RDW}$ & 0.33 \\
\hline & $\mathrm{DIA} 2=5.9698+4.934 \mathrm{RDW}$ & 0.71 & $\mathrm{HT} 3=18.9767+13.6173 \mathrm{RDW}$ & 0.48 \\
\hline & DIA3 $=14.1253+5.1585$ RDW & 0.65 & DIA1 $=3.6313+2.7409$ RDW & 0.61 \\
\hline & $\mathrm{DBH}=11.7942+1.8391 \mathrm{RDW}$ & 0.39 & $\mathrm{DIA} 2=4.3611+4.0546 \mathrm{RDW}$ & 0.59 \\
\hline & - & - & DIA3 $=4.7864+7.4356$ RDW & 0.71 \\
\hline \multirow[t]{6}{*}{$S: R$} & $\mathrm{HT} 1=28.184-2.7404 \mathrm{~S}: \mathrm{R}$ & 0.46 & $\mathrm{HT} 1=29.2843-4.0549 \mathrm{~S}: \mathrm{R}$ & 0.58 \\
\hline & $\mathrm{HT} 2=38.195-3.1397 \mathrm{~S}: \mathrm{R}$ & 0.34 & $\mathrm{HT} 2=32.8848-3.362 \mathrm{~S}: \mathrm{R}$ & 0.38 \\
\hline & $\mathrm{HT} 3=55.3009-3.1168 \mathrm{~S}: \mathrm{R}$ & 0.39 & $\mathrm{HT} 3=40.058-4.2104 \mathrm{~S}: \mathrm{R}$ & 0.25 \\
\hline & $\mathrm{DIA} 1=9.342-0.9784 \mathrm{~S}: \mathrm{R}$ & 0.58 & $\mathrm{DIA} 1=8.5226-1.1006 \mathrm{~S}: \mathrm{R}$ & 0.53 \\
\hline & DIA2 $=14.5736-1.9027 \mathrm{~S}: \mathrm{R}$ & 0.57 & DIA2 $=12.2393-1.8792 \mathrm{~S}: \mathrm{R}$ & 0.69 \\
\hline & $\mathrm{DIA} 3=24.3218-2.4586 \mathrm{~S}: \mathrm{R}$ & 0.80 & DIA3 $=15.7495-2.0849 \mathrm{~S}: \mathrm{R}$ & 0.30 \\
\hline \multirow{4}{*}{ FOLR } & $\mathrm{HT} 2=19.5464+1.2654$ FOLR & 0.44 & $\mathrm{HT} 1=8.9691+1.1848 \mathrm{FOLR}$ & 0.39 \\
\hline & DIA1 $=4.446+0.2852$ FOLR & 0.39 & $\mathrm{HT} 2=11.7598+1.4928$ FOLR & 0.59 \\
\hline & $\mathrm{DIA} 2=3.7084+0.7148 \mathrm{FOLR}$ & 0.63 & $\mathrm{HT} 3=8.6782+2.4567$ FOLR & 0.66 \\
\hline & DIA3 $=11.814+0.741 \mathrm{FOLR}$ & 0.57 & DIA1 $=2.1368+0.4255$ FOLR & 0.62 \\
\hline \multirow{5}{*}{ DQI } & $\mathrm{DIA} 1=5.3588+2.9251 \mathrm{DQI}$ & 0.60 & $\mathrm{HT} 2=19.5544+9.345 \mathrm{DQI}$ & 0.34 \\
\hline & $\mathrm{DIA2}=6.51+6.3163 \mathrm{DQI}$ & 0.73 & $\mathrm{HT} 3=20.5218+17.3247 \mathrm{DQI}$ & 0.49 \\
\hline & DIA3 $=14.7707+6.4441 \mathrm{DQI}$ & 0.64 & DIA1 $=3.9362+3.4993 \mathrm{DQI}$ & 0.63 \\
\hline & $\mathrm{DBH}=12.0626+2.2216 \mathrm{DQI}$ & 0.36 & $\mathrm{DIA2}=4.8335+5.1341 \mathrm{DQ}$ & 0.60 \\
\hline & 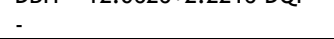 & - & $\mathrm{DIA3}=5.56+9.5987 \mathrm{DQI}$ & 0.75 \\
\hline
\end{tabular}



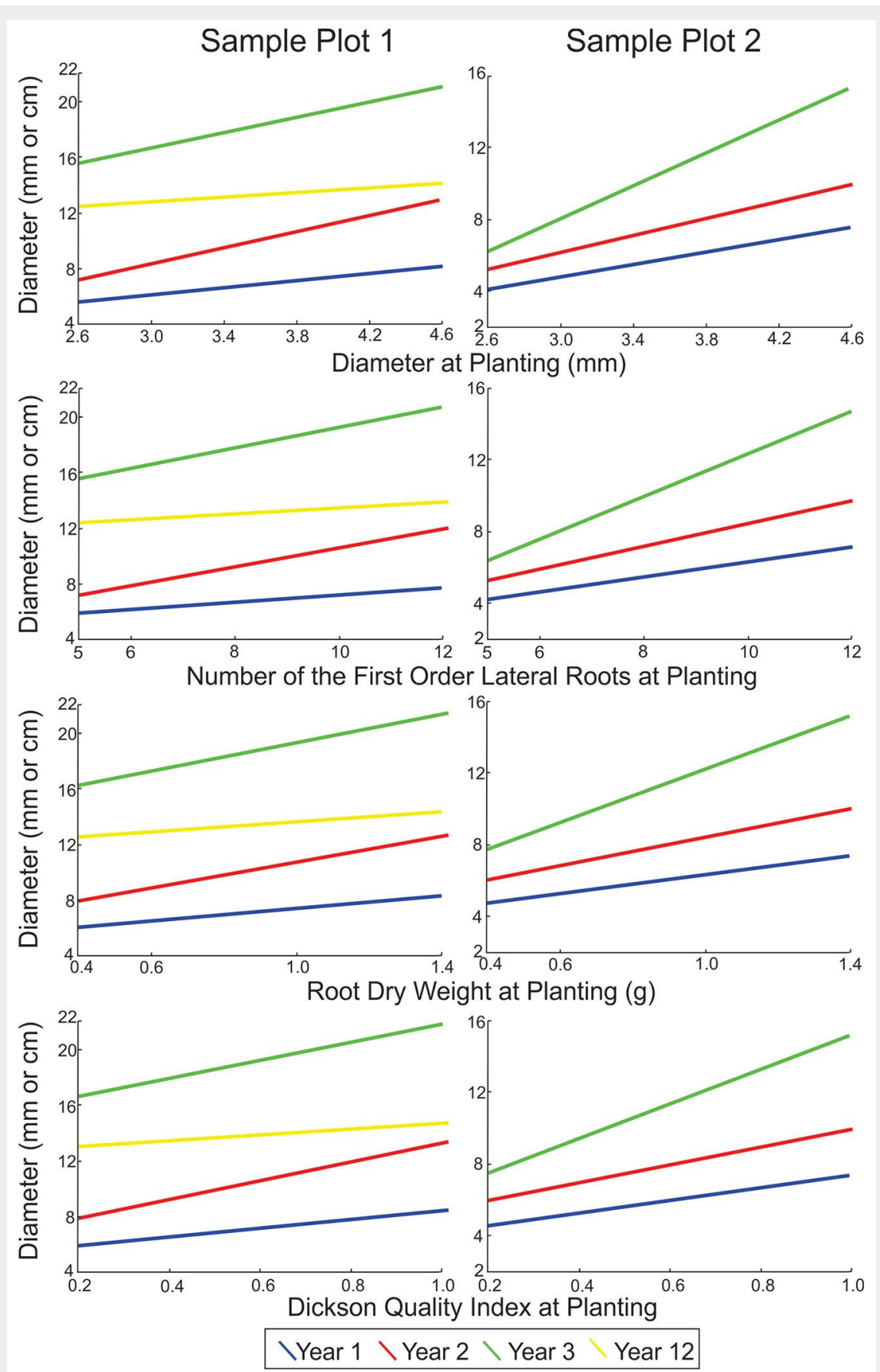

Fig. 3 - The relationship of initial diameter, number of the first lateral roots, root dry weight, and Dickson quality index of Austrian pine seedlings measured just prior to planting to diameter after one, two, three and 12 years of field growth at both sample plots (regression lines and coefficient of correlation for initial DIA and field performance after planting are given in Tab. 5). Diameter growth in years one, two and three is in $\mathrm{mm}$, while year $12 \mathrm{DBH}$ is in $\mathrm{cm}$. Only significant relationships are shown.

on SP2. Similar to DIA, initial RDW, FOLR, and DQI showed strong positive correlations with survival only on SP2. The strongest correlations for initial morphological attributes to survival at both sites were negative (HT, HD, and $S: R$ ). In general, initial seedling morphological attributes were more strongly related to survival at SP2.

Morphological attributes measured at lifting forecast field growth with varying levels of success at both SP1 and SP2. Initial seedling $H T, H D$, and $S: R$ were negatively related to field growth during years one to three, but did not forecast growth in year 12 (Tab. 4). In contrast, initial seedling DIA, RDW, FOLR, and DQI were positively related to field growth during years one to three on both sites. These morphological attributes, together with SDW, were able to forecast DBH 12 years after planting at SP1 $(R=0.5-0.63)$. In general, at the site with deeper soil profile (SP1), initial mor- phological attributes were better at forecasting growth compared to survival. Across both sites, five initial morphological attributes (HD, DIA, RDW, FOLR, and HT) consistently forecast HT and DIA growth during years one to three after planting.

All morphological attributes measured at lifting provided some indication of growth during the three years after planting at both SP1 and SP2. However, some attributes provided better forecasting potential (i.e., coefficients of determination $>0.50$ ). At both sites, HD most consistently explained a large proportion of the variation after planting for diameter and height growth from years one to three, followed by DIA, RDW, FOLR, and DQI, respectively (Tab. 5). HT also explained a proportion of the variation of after-planting diameter and height growth from years one to three, though at $\sim 11 \%$ to $17 \%$ less than DIA and HD, respectively. The SDW showed very little forecasting potential for seedling growth; in contrast, the S:R had good forecasting potential for seedling diameter growth.

No morphological attribute was able to forecast growth 12 years after planting at either SP, with threshold of $r^{2}>0.5$. There was no difference in the potential of morphological attributes to forecast field growth between the two sites. However, the relationship of seedling attributes to field growth was stronger for diameter than for the height growth. Examples of the positive correlations of initial DIA, RDW, and DQI with diameter growth from one to 12 years after planting at SP1 are shown in Fig. 3.

\section{Discussion}

\section{Seedlings, stock type, and site} conditions

HT of two-year-old Austrian pine seedlings in this study were shorter, though DIA were above average compared with seedlings typically produced in Serbian nurseries (Ivetić, unpublished data). Seedlings used in this study were graded as first-class based on DIA and second-class based on HT (Tab. 1). These stock types represented plant material typically used in Serbian reforestation programs.

Stock type had a significant influence on initial seedling size, as previously reported for Austrian pine seedlings (Djordjević 1991, Ivetić \& Škorić 2013). Bareroot seedlings had greater $H T, H D$, and $S: R$ ratios, while Gocko container seedlings had larger DIA, dry weights, numbers of FOLR, and DQI.

Site conditions had a strong effect on field performance of Austrian pine seedlings and increased with time. Year 2000 was the hottest and the driest during the establishment stage (see Supplementary Material), resulting in the highest mortality in the first three years after planting (Tab. 2). Higher mortality at SP2 was attributed to lower soil water capacity, due to shallow soil profile. Reforestation site environmen- 
tal conditions that cause planting stress (Grossnickle 2005a, 2016) can influence seedling survival and growth in the first few years after planting (Grossnickle 2000, Kolevska \& Trajkov 2012).

\section{Initial morphological attributes and \\ survival}

Higher survival and growth of smaller seedlings at SP2 was consistent with negative correlations between initial HT and survival after planting on droughty sites as previously reported for pines (Tuttle et al. 1988, Van Den Driessche 1991, McTague \& Tinus 1996). Initial DIA of Austrian pine seedlings was positively correlated with survival (Tab. 3), as previously reported for pines (South et al. 2005, Mexal et al. 2009, Oliet et al. 2009, Tsakaldimi et al. 2012). Stem diameter is a seedling attribute that forecast both survival and growth and is considered the single most useful morphological attribute to measure (Thompson 1985, Mexal \& Landis 1990).

It was difficult to separate the relationship between stem diameter and root mass (Grossnickle 2012). Similar to DIA, RDW and FOLR forecast survival only on $\mathrm{SP} 2$. The strong positive correlation of RDW and FOLR with survival for Austrian pine seedlings in this study is consistent with previously reported work on pines (Kormanik et al. 1988, Oliet et al. 2009).

Both ratios, HD and $S: R$, exhibited negative correlation with survival (Fig. 2), corroborating the findings of Johnson \& Cline (1991) that a low HD indicated higher survival potential on dry sites. Much stronger correlation between survival and HD at SP2 supports findings of South \& Mexal (1984) that this relationship is low for sites where moisture was abundant and high where moisture was limited. A strong negative correlation between S:R and survival (Tab. 3) agrees with reports that a larger shoot to root system reduces the deleterious effects of low soil moisture on seedling survival (Van Den Driessche 1991, Bernier et al. 1995, Tsakaldimi et al. 2012).

DQI forecast survival only on SP2 in the second and third years (Tab. 3). DQI has been positively related to the survival of pine seedlings (Tsakaldimi et al. 2012). Combinations of morphological attributes appeared to be useful indicators of field performance as long as the physiological status did not significantly differ among seedlings (Ritchie 1984, Mexal \& Landis 1990, Johnson \& Cline 1991). Our results showed that the value of this index in forecasting seedling survival was poorer than HT and $\mathrm{HD}$, which were non-destructive and easy to measure.

Our results indicated that a more balanced shoot system resulted in greater survival due to lower planting stress on harsh sites. This was consistent with results for other pine species (McTague \& Tinus 1996). A higher survival of smaller seedlings on droughty sites was explained by reduced water stress (Rose et al. 1993, Stewart \&
Bernier 1995) due to their lower shoot-toroot ratio (Grossnickle 2005b, 2012) and larger root systems (Burdett 1990, Grossnickle 2005a).

\section{Initial morphological attributes and growth}

Shorter seedlings may have had an advantage on droughty sites (Mexal \& Landis 1990, Grossnickle 2012), as shown for Austrian pine in this study. Austrian pine height at planting was negatively correlated with growth in first three years after planting at both locations. Our results suggest that Austrian pine seedlings were exposed to planting stress at both sites, given that there was a negative relationship between initial HT and height growth increment (South \& Zwolinski 1997).

At both SP1 and SP2, initial DIA had a strong positive correlation with growth after planting, as previously reported for pines (Ward et al. 2000, South et al. 2005, Mexal et al. 2009). Seedling DIA is a general measure of seedling sturdiness and root system size, and has been shown to be related to resistance against drought and heat damage (Mexal \& Landis 1990, Grossnickle 2012).

SDW was positively, but inconsistently, correlated with field growth during the first three years at both locations, but also positively correlated with DBH 12 years after planting on SP1. Positive correlation of initial SDW with growth is consistent with a previous report for other conifers (Hulten 1976).

RDW and FOLR were consistently and positively related to field growth at both sites. These correlations were stronger for diameter than height. At SP1, both attributes were used to forecast DBH 12 years after planting. Studies report a positive relationship between root system size and seedling growth after outplanting for pines (Rose et al. 1997, Dominguez-Lerena et al. 2006). FOLR was suggested as an attribute capable of forecasting seedling competitive potential after outplanting (Kormanik 1986), though it may have been a less accurate indicator of seedling morphological quality than other easily measured attributes (Jacobs \& Seifert 2004).

As with survival, both $\mathrm{HD}$ and $\mathrm{S}: \mathrm{R}$ ratios showed negative correlation with field growth. In general, a sturdiness ratio "should closely parallel diameter in predicting growth in the field" (Thompson 1985). A low HD ratio indicated the potential for greater growth on stressful sites (Johnson \& Cline 1991). In this study, the relative potential of HT and DIA to forecast growth after planting increased when combined in an HD ratio, with a high HD ratio resulting in reduced growth during the first three years after planting. Our study indicates the potential of $S: R$ for forecasting field growth of Austrian pine seedlings under limiting site conditions for up to three years after planting, despite previous reports of its limited use in evaluating con- tainer seedling quality (Bernier et al. 1995). The negative correlation of initial $S: R$ to subsequent growth in our study is consistent with the above discussion of $\mathrm{S}: \mathrm{R}$, seedling water balance, and survival. This study indicates the potential of this attribute in forecasting field growth of Austrian pine seedlings under limiting site conditions for up to three years after planting.

DQI showed potential to forecast field growth of Austrian pine seedlings similar to DIA, RDW, S:R, and FOLR. DQI was related to field performance of conifer seedlings (Ritchie 1984). However, DQI was no better than DIA. This indicates that single plant attributes, rather than DQI, may be just as effective at forecasting Austrian pine seedling field growth.

\section{Site conditions, time, and forecasting potential}

Correlations of initial morphological attributes with survival were much stronger at SP2. Results of our study support findings that initial morphological attributes are important in forecasting field survival when environmental stress occurs (reviewed by Thompson 1985, Mexal \& Landis 1990, Grossnickle 2012). A weak effect of site on correlations between initial values of plant attributes and growth is present only in the first and the twelfth years.

Initial morphological attributes of Austrian pine seedlings measured at lift showed a consistent ability to forecast field survival and growth for three years after planting at both SP. However, only a few of the measured attributes determined diameter growth 12 years after planting (Tab. 4), but below a threshold of $r^{2}>0.5$. The question, "How long can initial morphological attributes measured at lifting be used to forecast seedling field performance?" is critical when defining plant attributes to measure in a stock quality program. In the first year after planting, seedlings face the greatest obstacles to survival (Burdett 1990, Grossnickle 2005a) and their later survival and growth depends on inherent growth potential as well as planting site conditions (Grossnickle 2000). Our results support previous reports on the ability of initial seedling morphological attributes to forecast field survival (Oliet et al. 2009, Pinto et al. 2011b) and growth (Rose \& Ketchum 2003, South et al. 2001) in the first years after planting.

\section{Conclusions}

This study has offered a perspective into the use of seedling morphological attributes to forecast field performance of Austrian pine. The study tested initial morphological attributes of different stock types under different site conditions for a number of years, which provided a clearer understanding of their potential use and robustness to forecast field performance. Both survival and growth in first years after planting were positively correlated with DIA, RDW, FOLR, and DQI and negatively 
correlated with HT, HD, and S:R. Initial seedling HD ratio and DIA were sufficiently robust to be used to consistently forecast field performance of Austrian pine seedlings in the early years after planting under a range of site conditions. Seedling HT was the best single morphological variable that could forecast survival, while FOLR was the best single morphological variable to forecast growth at sites with a shallower soil profile. Despite strong correlation with growth, grading of Austrian pine seedlings only on HT should be avoided, since "above a minimum size, the best seedling height is a function of outplanting site conditions" (Mexal \& Landis 1990). Seedling overall size should be adjusted in relation to potential planting site environmental conditions (Grossnickle 2012). The HD ratio was the most reliable plant attribute used to forecast performance over three years after planting and should be used together with HT and DIA for seedling grading. This study also found that initial seedling morphological attributes are more useful on drier sites to forecast outplanting survival, and on sites with more favorable environmental conditions to forecast outplanting growth. However, there is a time limit to their effectiveness to define field performance.

Austrian pine is mainly used in Serbian reforestation and afforestation programs for harsh sites, usually as pioneer species. Defining reforestation success under unfavorable environments requires a precise measure of seedling quality. Simple, fast, and non-destructive measurements of aboveground morphological measurements, as presented in this study, are still best suited for most operational programs, especially if results are combined with knowledge about planting site conditions.

\section{References}

Bernier PY, Lamhamedi MS, Simpson DG (1995). Shoot:root ratio is of limited use in evaluating the quality of container conifer stock. Tree Planters' Notes 46: 102-106. [online] URL: http://www.cfs.nrcan.gc.ca/publications/? id $=33715$

Burdett AN (1983). Quality control in the production of forest planting stock. The Forestry Chronicle 59 (3): 132-138. - doi: 10.5558/tfc591323

Burdett AN (1990). Physiological processes in plantation establishment and the development of specifications for forest planting stock. Canadian Journal of Forest Research 20: 415427. - doi: 10.1139/x90-059

Djordjević D (1991). Comparative research of growth dynamics of Austrian pine (Pinus nigra Arn.) root system in the first year produced in the open and in the rigid containers. Bulletin of the Faculty of Forestry 73: 231-239. [in Serbian] Dominguez-Lerena S, Herrero Sierra N, Carrasco Manzano I, Ocana Bueno L, Penuelas Rubira JL, Mexal JG (2006). Container characteristics influence Pinus pinea seedling development in the nursery and field. Forest Ecology and Management 221: 63-71. - doi: 10.1016/j.foreco.2005.
08.031

Dunsworth GB (1997). Plant quality assessment: an industrial perspective. New Forests 13 (1-3): 439-448. - doi: 10.1023/A:1006519315955

Grossnickle SC (2000). Ecophysiology of northern spruce species: the performance of planted seedlings. NRC Research Press, Ottawa, Ontario, Canada, pp. 407. - [online] URL: http:// www.nrcresearchpress.com/doi/abs/10.1139/97 80660179599

Grossnickle SC (2005a). Importance of root growth in overcoming planting stress. New Forests 30: 273-294. - doi: 10.1007/s11056-004-83 03-2

Grossnickle SC (2005b). Seedling size and reforestation success. How big is big enough? In: "The thin green line: a symposium on the stateof-the-art in reforestation" (Colombo SJ ed). Forest Research Information Paper 160, Ontario Forest Research Institute, Ontario Ministry of Natural Resources, Sault Ste. Marie, Ontario, Canada, pp. 138-144. [online] URL: http://www.creditvalleyca.ca/wp-content/uploa ds/2011/02/the-thin-green-line-research-on-refor estation.pdf\#page $=145$

Grossnickle SC (2012). Why seedlings survive: importance of plant attributes. New Forests 43: 711-738. - doi: 10.1007/s11056-012-9336-6

Grossnickle SC (2016). Restoration silviculture: an ecophysiological perspective - Lessons learned across 40 years. Reforesta 1: 1-36. - doi: 10.21750/REFOR.1.02.2

Grossnickle SC, Folk RS (1993). Stock quality assessment: forecasting survival or performance on a reforestation site. Tree Planters' Notes 44: 113-121. [online] URL: http://s3.ama zonaws.com/academia.edu.documents/462519 40/

Grossnickle SC, South DB (2014). Fall acclimation and the lift/store pathway: effect on reforestation. The Open Forest Science Journal 7: 1-20. doi: $10.2174 / 1874398601407010001$

Hulten H (1976). How the physiologist can improve the raising of container grown stock and its establishment. Research Note no. 81, Department of Reforestation, Royal College of Forestry, Stockholm, Sweden, pp. 12.

Ivetić V (2015). Reforestation in Serbia: success or failure? In: Proceedings of the International Conference "Reforestation Challenges" (Ivetić V, Stanković D eds). Belgrade (Serbia) 03-06 Jun 2015. Reforesta, Belgrade, Serbia, pp. 1-12. Ivetić V, Devetaković J (2016). Reforestation challenges in Southeast Europe facing climate change. Reforesta 1: 178-220. [online] URL: http://www.reforestationchallenges.org/REFO R/index.php/REFOR/article/view/1

Ivetić V, Škorić M (2013). The impact of seeds provenance and nursery production method on Austrian pine (Pinus nigra Arnold) seedlings quality. Annals of Forest Research 56 (2): 297305. [online] URL: http://afrjournal.org/index.p hp/afr/article/view/29

Ivetić V, Vilotić D (2014). The role of plantation forestry in sustainable development. Bulletin of Faculty of Forestry (Special Edition): 157-180. [online] URL: http://search.proquest.com/open view/0259cocfobb575f6fefae2b753b7530c/1 Jacobs DF, Seifert JR (2004). Re-evaluating the significance of the first-order lateral root grading criterion for hardwood seedlings. In: Pro- ceedings of " $14^{\text {th }}$ Central Hardwood Forest Conference". General Technical Report NE-316, USDA Forest Service, North Central Forest Experimental Station, St. Paul, MN, USA, pp. 382388. [online] URL: http://www.researchgate. net/publication/228774574

Johnson JD, Cline ML (1991). Seedling quality of southern pines. In: "Forest Regeneration Manual” (Duryea ML, Dougherty PM eds). Kluwer, Dordrecht, The Netherlands, pp. 143-162. - doi: 10.1007/978-94-011-3800-0_8

Kolevska DD, Trajkov P (2012). Quality and development of containerized seedlings and stands of Austrian black pine (Pinus nigra Arn.) in the Republic of Macedonia (FYROM). Forestry Ideas 18 (1-43): 19-27. [online] URL: http://for estry-ideas.info/files/journal/Forestry_Ideas_BG 2012 1.pdf.pdf\#page $=19$

Kormanik PP (1986). Lateral root morphology as an expression of sweetgum seedling quality. Forest Science 32: 595-604. [online] URL: http:// www.ingentaconnect.com/content/saf/fs/1986/ $00000032 / 00000003 /$ arto0008

Kormanik PP, Ruehle JR, Muse HD (1988). Frequency distributions of seedlings by first-order lateral roots: A phenotypic or genotypic expression. In: Proceedings of " $31^{\text {st }}$ Northeastern Forest Tree Improvement Conference" and the " 6 th Northcentral Tree Improvement Association" (Maurice E, Demerit Jr eds). University Park (PA, USA) 7-8 Jul 1988. Penn State University, PA, USA, pp. 181-187.

McKay HM (1997). A review of the effects of stresses between lifting and planting on nursery stock quality and performance. New Forests 13: 369-399. - doi: 10.1023/A:1006563130 976

McTague JP, Tinus RW (1996). The effects of seedling quality and forest site weather on field survival of ponderosa pine. Tree Planters' Notes 47 (1): 16-32. [online] URL: http://agris. fao.org/agris-search/search.do?recordID=US199 7053023

Mexal JG, Cuevas Rangel RA, Landis TD (2009). Reforestation success in central Mexico: Factors determining survival and early growth. Tree Planters' Notes 53 (1): 16-22.

Mexal JG, Landis TD (1990). Target seedling concepts: height and diameter. In: Proceedings of Combined Meeting of the Western Forest Nursery Association Target Seedling Symposium. General Technical Report RM-200, USDA Forest Service, Fort Collins, CO, USA, pp. 17-36. [online] URL: http://www.rngr.net/publication s/proceedings/1990/mexal.pdf

Oliet J, Planelles R, Artero F, Valverde R, Jacobs $D$, Segura ML (2009). Field performance of Pinus halepensis planted in Mediterranean arid conditions: relative influence of seedling morphology and mineral nutrition. New Forests 37: 313-331. - doi: 10.1007/s11056-008-9126-3

Pinto JR, Dumroese RK, Davis AS, Landis TD (2011a). Conducting seedling stock type trials: a new approach to an old question. Journal of Forestry 109 (5): 293-299.

Pinto JR, Marshall JD, Dumroese RK, Davis AS, Cobos DR (2011b). Establishment and growth of container seedlings for reforestation: a function of stocktype and edaphic conditions. Forest Ecology and Management 261 (11): 18761884. - doi: 10.1016/j.foreco.2011.02.010 
Ranković N (2009). Afforestation in Serbia in the period 1961-2007 with special reference to Austrian pine and Scots pine. Bulletin of Faculty of Forestry 99: 115-134. [In Serbian]. [online] URL: http://scindeks.ceon.rs/article.aspx?artid=035345370999115R\&lang=en

Ritchie GA (1984). Assessing seedling quality. In: "Forest nursery manual: production of bareroot seedlings" (Duryea ML, Landis TD eds.). Martinus Nijhoff/Dr. W. Junk Publishers, The Hague, The Netherlands, pp. 243-266.

Rose R, Carlson WC, Morgan P (1990). The target seedling concept. In: Proceedings of the Combined Meeting of the Western Forest Nursery Association Target Seedling Symposium (Rose R, Campbell SJ, Landis TD eds). Technical Report RM-200, USDA Forest Service, Fort Collins, CO, USA, pp. 1-8. [online] URL: http://www. rngr.net/publications/proceedings/1990/rose.p df

Rose R, Gleason JF, Atkinson M (1993). Morphological and water-stress characteristics of three Douglas-fir stocktypes in relation to seedling performance under different soil moisture conditions. New Forests 7: 1-17. - doi: 10.1007/BFoo 037468

Rose R, Haase DL, Kroiher F, Sabin T (1997). Root volume and growth of ponderosa pine and Douglas-fir seedlings: a summary of eight growing seasons. Western Journal of Applied Forestry 12: 69-73. [online] URL: http://www.in gentaconnect.com/content/saf/wjaf/1997/0000 $0012 / 00000003 /$ art00003

Rose R, Ketchum JS (2003). Interaction of initial seedling diameter, fertilization and weed control on Douglas-fir growth over the first four years after planting. Annals of Forest Science 60 (7): 625-635. - doi: 10.1051/forest:2003055
Škorić A, Filipovski D, Cirić M (1985). Soil classification of Yugoslavia. ANUBiH, special edition book LXXVIII, volume 13, Department for Natural and Mathematical Sciences, Sarajevo, Bosnia and Herzegovina, pp. 1-72.

South DB, Zwolinski JB (1997). Transplant stress index: a proposed method of quantifying planting check. New Forests 13 (1/3): 315-328. - doi: 10.1023/A:1006546627342

South DB, Foster GS (1993). An experimental design for outplanting nursery trials on heterogeneous sites. South African Forestry Journal (165): 41-45. - doi: 10.1080/00382167.1993.9629 388

South DB, Harris SW, Barnett JP, Hainds MJ, Gjerstad DH (2005). Effect of container type and seedling size on survival and early height growth of Pinus palustris seedlings in Alabama, USA. Forest Ecology and Management 204: 385-398. - doi: 10.1016/j.foreco.2004.09.016 South DB, Mexal JG (1984). Growing the "best" seedling for reforestation success. Forestry Departmental Series No. 12. Alabama Agricultural Experiment Station, AL, USA, pp. 11.

South DB, Rakestraw JL, Lowerts GA (2001). Early gains from planting large-diameter seedlings and intensive management are additive for loblolly pine. New Forests 22: 97-110. - doi: 10.1023/A:1012097924355

Stewart JD, Bernier PY (1995). Gas exchange and water relations of 3 sizes of containerized Picea mariana seedlings subjected to atmospheric and edaphic water stress under controlled conditions. Annales des Sciences Forestieres 52 (1): 1-9. - doi: 10.1051/forest:19950101

Stilinović S (1987). Seedling production of forest and decorative trees and shrubs. University of Belgrade, University book press, Belgrade, Ser- bia, pp. 455. [In Serbian]

Thompson BE (1985). Seedling morphological evaluation: what you can tell by looking. In: "Evaluating seedling quality: principles, procedures, and predictive ability of major tests" (Duryea ML ed). Forest Research Laboratory, Oregon State University, Corvallis, OR, USA, pp. 59-72.

Tsakaldimi M, Ganatsas P, Jacobs DF (2012). Prediction of planted seedling survival of five Mediterranean species based on initial seedling morphology. New Forests 44: 327-339. - doi: 10.1007/s11056-012-9339-3

Tuttle CL, South DB, Golden MS, Meldahl RS (1988). Initial Pinus taeda seedling height relationships with early survival and growth. Canadian Journal of Forest Research 18: 867-871. doi: $10.1139 / \times 88-133$

Van Den Driessche R (1991). Influence of container nursery regimes on drought resistance of seedlings following planting: survival and growth. Canadian Journal of Forest Research 21: 555-565. - doi: 10.1139/x91-077

Ward JS, Gent MPN, Stevens GR (2000). Effects of planting stock quality and browse protection-type on height growth of northern red oak and eastern white pine. Forest Ecology and Management 127 (1-3): 205-216. - doi: 10.1016/ S0378-1127(99)00132-2

\section{Supplementary Material}

Appendix 1 - Weather conditions at Mt. Goč (1999-2010).

Link: Ivetic_1722@supploo1.pdf 